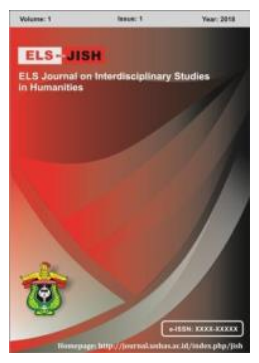

ELS-JISH

ELS Journal on Interdisciplinary Studies on Humanities

Volume 3 Issue 3, 2020

ISSN (print) : 2621-0843

ISSN (online) : 2621-0835

Homepage : http://journal.unhas.ac.id/index.php/jish

\title{
Syntactic Analysis of Donald Trump's Inaugural Speech
}

\section{Olusegun Oladele Jegede ${ }^{1}$}

\author{
1'jegedeolusegun@yahoo.com
}

\begin{abstract}
This study aimed at examining the syntactic devices in the inaugural speech of Donald Trump. The study adopted a quantitative and qualitative method. The study used frequencies and statistics to examine the frequency of occurrence of the syntactic devices used in the speech. The study also focused on how the devices helped in the interpretation of the speech. The speech was critically read. The syntactic devices (sentence types, modality, conjunctions, adverbials and pronouns) used in the speech were identified, categorised, interpreted and discussed according to the ideas presented in the speech. The findings revealed that the types of sentences employed were simple, complex, and compound sentences. He used more of simple sentences to achieve succinctness in his speech. He also used syntactic devices such as modal verbs, conjunctions, personal pronouns and adverbial phrases to accomplish conciseness, logicality, accuracy and effectiveness in his speech. The study concluded that the use of syntactic devices helped the speaker to achieve cohesion in the speech, thereby enabling him to express his motives, plans, feelings, and expectations from the Americans.
\end{abstract}

Keywords: Syntax, Political discourse, Inaugural speech, Language and ideology

How to cite: Jegede, O. O. (2020). Syntactic Analysis of Donald Trump's Inaugural Speech. ELS Journal on Interdisciplinary Studies in Humanities, 3(3), 317-327. DOI: https://doi.org/10.34050/elsjish.v3i3.11068

\section{Introduction}

Inauguration is an event that marks the beginning of a new administration of a public office holder. During this ceremony, the newly elected president is expected to give a speech. This speech is called inaugural speech and is generally classified as a political speech. Politician's speeches serve the purpose of making politicians seem more truthful in order to give citizens a sense of belonging and security (Jegede, 2018; Abuya, 2012). Political discourse has been the interest of several scholars in recent times. For instance, Beard (2002) maintains that it helps us understand how politicians use language to practice politics. Jegede (2019) notes that the language of politics is special compare to our day to day use of language, because it unravels politicians intentions.

Jegede $(2018,2019)$ claims that the language of politics enables politicians to explore the features of language to manipulate, persuade, appreciate, influence and make their intention known to the people. Similarly,

${ }^{1}$ Department of English and Literary Studies, Lead City University, Nigeria 
Schaffner (2004) observes that political discourse has been used either to represent the language use in the political context, to achieve a politicallymotivated goal. Jegede (2018) observes that language has become a political tool. In this regard, language is an important tool in carrying out political duties. Joseph (2002) argues that language is political because of the way in which it is used. Thus, our thoughts and views are determined by the options made available to us by our language (Jegede, 2015).

Several studies have been carried out on political speeches (Jegede, 2018, 2019; Ayodabo, 2003; Ademilokun, 2016; Ademilokun \& Taiwo, 2013; Aduradola \& Ojukwu, 2013; Arnurudu \& Oduola, 2017; Irimiea, 2010; Koussouhon \& Dadjo, 2016; Okoye \& Mmadike, 2016; Opeibi, 2007; Osisanwo, 2011; Osisanwo, 2016; Oyeleye \& Osisanwo, 2013a; Oyeleye \& Osisanwo, 2013b; Pengsun \& Fenfeng, 2013; Taiwo, 2014; Ugwu, 2003; Wei, 2001). A few studies have also been carried out on inaugural speeches (Abuya, 2012; Sharndama, 2015; Zhang \& Mingxia, 2009; Haoming, 2019; Liu, 2012; Chen, 2018; Sarah \& Oladayo, 2018; Murana, 2011). However, little has been done on the syntactic aspects of the inaugural speech of Donald Trump. Hence this study examined the use of grammatical devices used in the inaugural speech of Donald Trump.

\section{Literature Review}

\subsection{Inaugural Speech}

Speeches are often written to make the politician seem more trustful and make them feel more safe. It refers to the vocalized form of communication. Ayeomoni (2001) says during the inaugural ceremony, the president delivers a speech to inform his/her intentions as a leader. This enables politicians to have a logical and skilful way of handling language during their public communications.

Inaugural is an event formally placing someone in an office or position, especially the presidential position. An inaugural address is the first address given by the political office holder, especially during his inauguration (Ademilokun, 2015). In Nigeria, Politicians use the speech as an opportunity to win the hearts of their people and reemphasize their promises during their campaigns. Political discourse as speech or discourse is a very important tool in politics. Jegede (2018) notes that it plays an important role in making the people to have a positive opinion about the politicians as they use words to manipulate the minds and thoughts of the people. Thus, language in politicians' hands is a tool for manipulation in other to suit their intentions (Ayeomoni, 2001).

Political speeches are inevitable, considering that politics is popular and important in many parts of the world, so are Political speeches. Generally, politics occupies cogent aspects of human affairs; different people deliver political speeches at different political meetings. However, there is more attention on presidential speeches because generally, presidential speeches are delivered by a President of a country in different political contexts such as independence days, New Year day and more importantly, inauguration ceremonies. Irimiea (2010) notes that political speeches are sought after 
because what politicians say, how they say it, and where they say it matter. The popularity of political speeches has no doubt contributed to the entrenchment of the field of knowledge known as political discourse and the growth of research in the areas.

\subsection{Political Discourse}

Language has an important role to play in politics because it influences all political activities in a country (Sarah \& Oladayo, 2018). Beard (2000) observes that political discourse, language use in politics, helps to know how political office holders use language. Politicians, especially presidents and governors, use language skilfully in their speeches to persuade the people. According to Sarah \& Oladayo (2018), language and power are inter-related. Thus, everyone in power utilises language as a valuable tool in carrying out their official duties. In most cases, politicians manipulate their words in order to achieve their intentions. We can therefore say that language is the channel of politics.

Opeibi (2009) observes that language is the means by which politicians express their thoughts and ideologies. Therefore, the status of language in mobilising, convincing, enlightening and persuading the people cannot be overemphasized. Jegede (2019) notes that the masses usually give their support to politicians because of the way they use language to make their messages logical and accurate. Thus, the success of a politician greatly depends on how well they can use language to manipulate the psyche of the people. Chen (2018) observes that political discourse or speech is a social norm, which plays an important role in actualising the goals of the speaker.

According to Chen (2018), inaugural speeches, given by the president of the United State of America, reveal the attitude of the president to the internal and international issues surrounding the country. In such speeches, Presidents reveal new policies and acts relating to all the sectors in the country. Such speeches show their determination, confidence and focus to take effective measures to achieve the set developmental goals of the country. Thus, politicians use language skilfully to interact with the people, arouse their passions and seek their support. This is the interest of studies in political discourse.

\subsection{Syntax}

Andrew (2006) defines syntax as 'a set of rules, principles, and processes that govern the structure of sentences in a given language, usually including word order'. The goal of scholars in this field is to bring out the rules of the syntax of a particular language, in this case, the English language (Robert and Howard, 2006). Syntax is the study of word combination to form phrases, from phrases to clauses and finally clauses to sentences or utterances. Syntax mainly focuses on grammaticality and acceptability. The analysis of syntactic structure in a text can be determined by analysing the compositions of the sentences in the text. These include sentence types according to function and structure, Tenses, Adjunct, Anaphora, Appositives, Conjugation, Conjunction, Clause, Constituent, Coordination, Co-reference, Dependent marking, Determiner, Discontinuity, Modal particle, Modal verb, Modifier, Mood, Negative inversion, Word class, Part of speech, Phrasal verb, Predicative expression, 
Preposition and postposition, Pronoun, Restrictiveness, etc. Syntactic analysis is very wide; however, this study is limited to sentence types, modality, conjunctions, adverbs and pronouns.

\section{Methodology}

This study adopted a quantitative and a qualitative approach. The study used frequencies to examine the occurrence of the syntactic devices used in the speech. This made the study flexible and ensured a reliable data analysis. The study also focused on how the syntactic devices helped in interpreting of the ideologies expressed in the speech. Donald Trump's inaugural speech served as the subject and data for this study. The speech was critically read and the syntactic devices such as sentence types, modality, conjunctions, adverbials and pronouns used in the construction of the speech were identified, categorised, interpreted and discussed in relation to the ideas relayed in the speech.

\section{Results and Discussion}

\subsection{Sentence Types}

\section{a. Structural Sentence Types}

Table 1 below shows the frequency of use of structural sentence types in the speech.

Table 1. Frequency of the Use of Structural Sentence Types

\begin{tabular}{ll}
\hline Structural Sentence Types & Frequency \\
\hline Simple Sentence & 24 \\
\hline Compound Sentence & 20 \\
\hline Complex Sentence & 27 \\
\hline Total & $\mathbf{7 1}$ \\
\hline
\end{tabular}

From the table above, we will observe that the speaker uses simple sentences 24 times in his speech. The purpose is to make is speech clear understandable and simple to the audience. The following are some of the simple sentences used:

1) "America will start winning again"

2) "We will shine for everyone to follow"

3) "There is no room for prejudice"

4) "These are just and reasonable demand"

From the following we notice that the speaker tries to make his speech simple and clear at the same time being emphatic and passionate.

Similarly, the author makes use of compound sentences 20 times to make his speech more emphatic and concise. He has a lot to say within a short time, so with the help of compound sentences, he is able to bring two to three ideas together in one sentence. Consider the following extracts: 
1) "Washington flourished but the people did not share in its wealth"

2) "Politicians prospered but the jobs left and the factories closed"

3) "The establishment protected itself but not the citizens of our country"

Trump also makes use of complex sentences 27 times in his speech. He uses this sentence type more often than the simple and compound sentences because it enables him to bring multiple ideas together in a sentence while still keeping the sentences clear and informative. The following are some of the complex sentences used:

1) "Today's ceremony, however, has very special meaning because today we are not merely transferring power from one administration to another"

2) "For too long a small group in our nation's capital has reaped the rewards of government while the people have borne the cost"

\section{b. Functional Sentence Types}

Table 2 below shows the frequency of use of the functional sentence types in the speech.

Table 2. Frequency of the Use of Functional Sentence Types

\begin{tabular}{ll}
\hline Sentence Types & Frequency \\
\hline Declarative Sentence & 68 \\
\hline Imperative Sentence & 01 \\
\hline Interrogative Sentence & 00 \\
\hline Exclamatory Sentence & 00 \\
\hline Optative Sentence & 02 \\
\hline Total & 71 \\
\hline
\end{tabular}

According to the table above, the Trump uses 70 declarative sentences in the speech. The use of declarative sentences enables the speaker to clearly state his goals and declares the objectives of his administration. Since the speaker is just starting an administration, all he has to do is to give his audience all the information they need about his administration. Thus, he has to use mainly declarative sentences. The following are some extracts:

1) "We will seek friendship and goodwill with the nations of the world - but we do so with the understanding that it is the right of all nations to put their own interests first"

2) "We do not seek to impose our way of life on anyone, but rather to let it shine as an example for everyone to follow"

3) "We will reinforce old alliances and form new ones - and unite the civilized world against Radical Islamic Terrorism, which we will eradicate completely from the face of the Earth"

The imperative sentence is used once in the speech. The speaker uses it to request for his listeners' support and to express his ideas more powerfully and zealously. He also uses it to stimulate the listeners' interest and actions, and most importantly, instil confidence in them during his administration. This is seen in the extract below:

1) Do not let anyone tell you it cannot be done. 
Interrogative and exclamatory sentences are not used at all throughout the speech. This could be due to the fact that in speaker is not interested in asking questions from the audience or showing different emotions. His interest is in revealing his plans, which he has done through the use of declarative sentences.

However, he uses 2 optative sentences in his speech to wish the Americans and America God's blessings during his tenure. This is shown in the extracts below:

"God bless you"

"And God bless America"

\subsection{Modality: The Use of 'Will' and 'Must'}

The modal verb 'will' is mostly used in the speech because the speech focuses on the future, that is, revealing future plans. 'Must' is sparingly used to expresses necessity, commands, insistent requests and counsel in the speech. The frequency of use of the modal verbs 'will' and 'must' in the speech is shown in the table below.

Table 3. Frequency of the Use of 'Will' and 'Must'

\begin{tabular}{cc}
\hline Use of 'Will' and 'Must' & Frequency \\
\hline Will & 33 \\
\hline Must & 01 \\
\hline Total & $\mathbf{3 4}$ \\
\hline
\end{tabular}

As shown in the table above, the modal 'will' is the most frequently used modal. This reveals that the president makes known his plans and wants the Americans to join him in order to achieve the plans. As a newly elected president, he tries to make his intentions known to the Americans and the world at large. Also, he uses the modal 'will' to relay what lies ahead, and the use of modal 'must' to show his commitment in his plans as seen in the following exacts:

1) "We will face challenges"

2) "We will confront hardships"

3) "We will bring back our jobs"

From the extract above, the speaker makes his intentions known to the citizens. He also tries to build confidence in them so that they will rest assured that his tenure will be in their favour, and the country will benefit immensely. He makes use of the expression, 'we will to remind the citizen that his administration is a collective effort.

\subsection{Conjunctions}

Conjunctions are of three types - coordinating conjunctions, correlating conjunctions and subordinating conjunctions. This study focuses only on the coordinating conjunctions used in the speech. The frequency of the use of the conjunctions is shown in the table below. 
Table 4. Frequency of the Use of Conjunctions

\begin{tabular}{cc}
\hline Use of Conjunctions & Frequency \\
\hline And & 58 \\
\hline But & 10 \\
\hline Or & 03 \\
\hline For & 00 \\
\hline Yet & 00 \\
\hline So & 00 \\
\hline Total & $\mathbf{7 1}$ \\
\hline
\end{tabular}

The table reveals that 'and' is used in the speech 58 times, 'but' 10 times, and 'or' 3 times. 'And' has the highest frequency because Trump tries to reveal that actions or instances of two or more events will occur at the same point in time or space during his administration. Thus, he uses 'and' to show noncontrasting event(s) or idea(s). He uses 'but' to show contrasts or exceptions in his plans and scarcely uses 'or' to show alternative plans or ideas. The following are extracts from the speech.

1) "But that is the past and now we are looking only to the future"

2) "Every decision on trade, on taxes, on immigration, on foreign affairs will be made to benefit American workers and American families"

3) "The establishment protected itself but not the citizens of our country"

4) "What truly matters is not what party controls our government but that this government is controlled by the people"

5) “... whether we are black or brown or white, we all bleed the same red blood of patriots"

6) " ... whether a child is born in the urban sprawl of Detroit or the windswept plains of Nebraska, they look at the same night sky ..."

From the extracts, we will observe that the speaker uses the conjunctions to lay emphasis on certain issues such as equality, unity, and better governance. He also uses them to strengthen and affirm what he promised them during his campaign.

\subsection{Pronouns}

This analysis focuses on personal pronouns only. Personal pronouns take the place of common and proper nouns. The following table reveals the frequency of use of personal pronouns in the speech.

Table 5. Frequency of the Use of Personal Pronouns

\begin{tabular}{lll}
\hline Use of Personal Pronouns & Frequency \\
\hline First Person & $\mathrm{I}$ & 02 \\
\cline { 2 - 3 } & $\mathrm{We}$ & 35 \\
\hline Second Person & $\mathrm{You}$ & 04 \\
\hline Third Person & $\mathrm{He}$ & 00 \\
\cline { 2 - 3 } & She & 00
\end{tabular}




\begin{tabular}{ccc}
\hline & It & 03 \\
\hline Total & & $\mathbf{4 4}$
\end{tabular}

The above table shows the frequency of use of personal pronouns by the President in his speech. The president uses the first person personal pronouns 'I' 2 times and 'we' 35 times. He uses ' 1 ' when he shows the Americans his determination and readiness. The frequent use of 'we' shows that the President's speech focuses on the Americans rather than himself only. He uses 'you' only 4 times when trying to gain or regain the attention of the audience. He doesn't use 'he' and 'she' at all because he is not referring to any third party. The speech is between him and the Americans. However, he uses 'it' 3 times to refer to America (1 time) and power (2 times). The following are some extracts from the speech:

1) "I will fight for you with every bone in my body and I will never ever let you down."

2) "Together we will determine the course of America for many, many years to come"

3) "Together we will face challenges. We will confront hardships. But we will get the job done"

4) "We the citizens of America have now joined a great national effort to rebuild our county and restore its promise for all our people"

5) “Today's ceremony, however, has very special meaning because today we are not merely transferring power from one administration to another - but transferring it from Washington DC and giving it back to you the people"

\subsection{Adverbials}

Occasionally, Trump begins his sentences with adverbials. This is shown in the extracts below:

1) "Together, we will determine the course of America and the world for years to come"

2) "For too long, a small group in our nation's capital has reaped the rewards of government while the people have borne the cost"

3) "From this moment on, it's going to be America first"

From the extracts above, we will observe that the adverbial groups are fore-grounded. What this means is that the adverbs are given prominence. In other words, Trump tries to expose the Americans to the different challenges which they are facing and those they will face in the near future. Thus, he uses adverbs to let the audience know that his administration gives priority to unity and solution to their long-term challenges and mistakes - defending, providing for, and boosting the economy of other countries at their own expense.

\section{Conclusion}

This study reveals that the types of sentences employed are simple, complex, and compound sentences. He uses more of simple sentences to 
achieve succinctness in his speech. He employs more of the future modality to express his plans for the Americans. He also uses a wide range of means such as adverbials and pronouns to accomplish conciseness, logicality, accuracy and effectiveness in his speech. The different syntactic devices help the speaker in achieving cohesion in the speech, which in turn enables the readers and listeners to connect with him and his plans. The syntactic devices also provide an avenue for researchers to explore the functionality of language as a mean of connectedness between what is said and what is meant. Thus, the devices are used to show motives, plans, feelings, and his expectations from the Americans. With the grammatical features, Donald Trump was able express his thoughts clearly, logically and powerfully. He is able to give a short, coherent and precise with the employment of the devices. Inaugural speeches need words well-formed into sentences, well-organized structures and well-linked sentences to form good paragraphs. The speaker uses the syntactic features to achieve this as well as persuasiveness in his speech. He was also able to achieve a high level of unity with and strong appeal to the audience.

\section{References}

Abuya, J. (2012). A Pragma-Stylistic Analysis of President Goodluck Ebele Jonathan inaugural speech. English Language Teaching, 5 (11), 8-15.

Ademilokun, M. \& Taiwo, R. (2013). Discursive strategies in newspaper campaign advertisements for Nigeria's 2011 elections. Sage, 7(4), 435455.

Ademilokun, M. (2016). Appraisal of resources in post-election defeatconcession speeches of some gubernatorial candidates in Southwestern Nigeria, 2014-2015. Africology: The Journal of Pan African Studies, 9(1), 167-187.

Aduradola, R. R. \& Ojukwu, C. (2013). Language of political campaign and politics in Nigeria. Canadian Social Science, 9(3), 104-116.

Akinkurolere S. O. (2013). Students' perception on the use of humor in the teaching of English as a second language in Nigeria' International Education Research. 1 (2): 65-73.

Andrew, C. (2006). Syntax: A Generative Introduction (2nd ed.). Oxford: WileyBlackwell.

Arnurudu, S. M. \& Oduola, T. A. (2017). A critical discourse analysis of concession speeches: Goodluck Jonathan, Kayode Fayemi and Mitt Romney. Journal of Humanities and Social Science, 22(3), 15-26.

Ayeomoni, M. O. (2001). Style in Nigerian Political Speeches. IFE Studies in English Language, 5, 15-27.

Ayodabo, J. O. (2003). A pragma-stylistic study of M.K.O. Abiola's Historic Speech of June 24, 1993, in Adebayo Lawal (ed) Stylistics in Theory and Practice. Ilorin: Unilorin Press.

Beard, A. (2000). The Language of Politics. London: Routledge. 
Chen, W. (2018). A Critical Discourse Analysis of Donald Trump's Inaugural Speech from the Perspective of Systemic Functional Grammar. Theory and Practice in Language Studies, 8(8), 966-972.

Haoming, L. (2019). A Stylistic Analysis of Donald Trump's Inaugural Address. Studies in Literature and Language, 19(3), 75-80.

Irimiea, S. (2010). A rhetorical and comparative study of the victory speeches of Barack Obama and Mircea Geoana. Journal of Linguistic Intercultural Education, 3, 41-53.

Jegede, O. O. (2015). Language and Ideology in the Media: A Study of Nigerian Newspaper Editorials. International Journal of English Literature and Culture, 3(3), 76-84.

Jegede, O. O. (2018). Interpersonal Meaning in Nigeria's President Muhammadu Buhari's 2015 Victory Speech. Papers in English and Linguistics (PEL), 19(3\&4), 183-195.

Jegede, O. O. (2019). Lexical Relations in Muhammadu Buhari's 2018 Democracy Day Speech. Journal of Management, Skills and Techniques, 4(2), 75-90.

Joseph, J. (2006). Language and Politics. Edinburgh: Edinburgh University Press. R. (1999). There goes the other foot - a reply to Short et al., Language and Literature, 8 (1), pp. 59-66.

Joseph, R. (1999). There goes the other foot - a reply to Short et al., Language and Literature, 8 (1), 59-66.

Koussouhon, L.A. \& Dadjo, S.D.Y. (2016). Pragmatic analyses of President Goodluck Jonathan's concession speech and General Muhammadu Buhari's acceptance speech: a comparative appraisal . International Journal of Applied Linguistics \& English Literature, 5(4), 12-19.

Leech, G. (2009). A Glossary of English Grammar. Edinburgh.

Liu, F. (2012). Genre Analysis of American Presidential Inaugural Speech. Theory \& Practice in Language Studies, 2(11), 28-40.

Murana, M. O. (2011). 'The dimension of interaction in public speeches: A mood analysis of President Obama's inaugural speech'. Papers in English and Linguistics (PEL). OAU, lle-lfe. Pp 230-46.

Okoye, A. N. \& Mmadike, B. I. (2016). A study of concession speech by President Goodluck Jonathan. Unizik Journal of Arts and Humanities, 17(1), 156-166.

Opeibi B. O. (2009). Discourse, Politics and the 1993 Presidential Election Campaigns in Nigeria. Lagos: Nouvelle Communications Limited.

Opeibi, B. O. (2009). Discourse, politics and the 1993 presidential election campaigns in Nigeria. Lagos: Nouvele Communications Limited.

Opeibi, T. (2007). One message, many tongues: An exploration of media multilingualism in Nigerian political discourse. Journal of Language and Politics, 6(2), 223-248. 
Osisanwo, A. (2011). Empowerment through language: mood in selected political posters in Nigeria. In Wale Osisanwo and C.N. Kammelu (Eds.) Empowerment through language, linguistics and literature. Ago-Iwoye: Olabisi Onabanjo University Press. 197-222.

Osisanwo, A. (2016). Representation of Nigerian general elections \& social actors in selected Nigerian news magazines' reports. In A. Odebunmi, A. Osisanwo, H. Bodunde \& S. Ekpe (Eds.) Grammar, applied linguistics and society (248-265). Ile Ife: OAU Press.

Oyeleye, L. \& Osisanwo, A. (2013a). Expression of ideologies in the media representation of the 2003 and 2007 general elections in Nigeria.' Discourse and Society, 24(6), 763-773.

Oyeleye, L. \& Osisanwo, A. (2013b). Lexicalisation in media representation of the 2003 and 2007 general elections in Nigeria. World Journal of English Language, 3(2), 1-9.

Pengsun, J. \& Fenfeng, L.U. (2013). A contrastive study of political speeches in presidential election of interpersonal meaning. Studies in literature and language, 6(3), 79-83.

Robert, F. and Howard, L. eds. (2006). Syntax. Critical Concepts in Linguistics. New York: Routledge.

Sarah, B. \& Oladayo, B. M. (2018). Language In Political Discourse: A Pragmatic Study Of Presupposition And Politeness In The Inaugural Speech Of President Donald Trump. Bulletin of Advanced English Studies, 1(1), 64 - 76.

Schaffner, C. (2004). Political discourse analysis from the points of view of translation Studies. Journal of Language and Politics, 3(1), 117-150. Schaffher, C. Politics as Text and Talk: Analytical Approaches to Political Discourse, Amsterdam: John Benjamin's Publishing Company.

Sharndama, E. C. (2015). Political discourse: A critical discourse analysis of President Muhammadu Buhari's inaugural speech. European Journal of English Language and Linguistics Research, 3(3), 12-24.

Taiwo, O. E. (2014). A Critical discourse analysis of modals in Nigerian political manifestos. International Journal of Linguistics, 6(3), 109- 117.

Ugwu, E. N. (2003). The rhetoric and propaganda of political campaigns in Nigeria. Journal of the Linguistic Association of Nigeria, 10, 9-26.

Van Dijk, T. A. (ed.) (2002) Politics as Text and Talk: Analytic Approaches to Political Discourse. Amsterdam: John Benjamins Publishing Company.

Wei, J. M. Y. (2001). Gender differentiation in political discourse: A case study of the 1998 Taipei Mayoral election. Shida Journal of Social Sciences, 10(2000), 29-44.

Zhang, L. \& Mingxia, H. (2009). The stylistic analysis on the data retrieval to Obama's inaugural speech. The Journal of Baicheng Normal Institute, 4, 48-52. 